\title{
Fra røgterdreng til redaktør
}

\author{
af Bjørn Svensson
}

A. Svensson (1880-1963) var gennem mange år med til at prage sønderjysk politik og presse. Det var imidlertid ingen selvfølge, at han opnåede denne stilling. Han var født som svensk statsborger $\mathrm{i}$ et fattigt skrædderhjem, og det krævede opmærksomhed fra flere velyndere at bane vejen til en dansk gerning $i$ grænselandet. Sønnen redaktør Bjørn Svensson beretter her om faderens barndom og hans valg mellem Sverige og Sønderjylland $\mathrm{i}$ årene frem til 1903. På dette tidspunkt blev han sikret tilknytning til sønderjysk presse, og kun fire år senere redaktør.

Det var den selvstændige, selvbevidste og stejle sønderjyske bondestand, der var det bærende befolkningslag i nationalitetskampen under fremmedherredømmet. Men den sønderjyske presse, der stod i frontlinien, hentede sine våbendragere også andetsteds.

Et vidnesbyrd om den brede rekruttering kan man finde $i$ et brev, som redaktør Jens Jessen, selv lærersøn, den 28. maj 1906 skrev til journalist A. Svenssons hustru: $»$ Med alle sine unoder, som jeg nok skal blive ved at pille ved, har Deres mand en meget stor fordel. Han har ubestridelig samfundsfølelse, almensans. Og medens han kan være utrolig taktløs og uforstandig paa andre punkter - han spurgte mig i paasketiden rasende, om jeg maaske ogsaa mente, han var udgaaet fra et tarveligt hjem (medens Christiansen ganske rolig som noget selvfølgeligt tager imod, at jeg siger, han og Deres mand har paa kontoret den mindste velopdragenhed, fordi de er udgaaet fra de tarveligste hjem) - saa har han, Deres gode mand, et sundt instinkt og en forstandig opfattelse med hensyn til folkelige formaal.«'

Redaktør Jessen havde ret $\mathrm{i}$, at både Ernst Christiansen og A. Svensson kom fra tarvelige hjem, tarvelige forstået som fattige. Christiansens far var postbud, Svenssons var skrædder. Men det er et spørgsmål, hvem der her har optrådt mest taktløs, og man behøver jo ikke at ligge under for autoriteter, fordi man kommer fra små kår. Som man ser, lå Svensson ikke under for redaktør Jessens autoritet, selv om han ellers var en stor beundrer af sin principal. $^{2}$

At Svensson regnede sit barndomshjem for et godt hjem, fremgår tydeligt af en skildring, han har givet af sin mor. ${ }^{3}$ Men der gemmer sig måske lidt af et forbehold i denne bemærkning: "Far lærte jeg først ret at forstaa, da jeg blev voksen, og han selv forlængst laa under mulde. « Svensson var 27 år, da faderen - Elias Svensson - døde, så forståelsen må være kommet sent. Man 
kan undre sig over, at den i det hele taget kom, for faderens specielle forhold gjorde, at hjemmet kom til at mangle andet end det materielle.

\section{Barndomshjemmet}

Min far, Adolph Bernhard Svensson, ${ }^{4}$ blev født i Løjt Kirkeby ${ }^{5}$ den 19. november 1880 . Han brød sig ikke om fornavnet, og som voksen skrev han blot: A. Svensson. Lad os da i det følgende betegne ham med A.S.

A.S. var fra fødselen svensk statsborger. Hele familien fulgte jo i så henseende familiefaderen, og denne stammede fra Sverige. Nærmere betegnet fra "det gamle danske grænseland, Halland«, som A.S. altid betonede, når han senere af tyskerne blev drillet med sin udenlandske afstamning.

Elias Svensson blev født på et husmandssted i Träslöv ved Varberg den 11. maj 1847 som den sidste af en række på seks børn. Hans forældre var Rotebåtsmannen Sven Nilsson Blom (f. 28. maj 1799) og Anna Perdotter (f. 8. januar 1806). En rote (rode) var en enhed i militærforvaltningens inddeling, og husmandsbruget stod til rådighed som modydelse for tjeneste $i$ flåden.

Moderen døde nytårsaften 1848, da Elias var halvandet år, og han fik stedmoder i 1850 . Arkiverne registrerer først igen Elias, da han arbejder som karl på forskellige gårde på egnen i perioden 1864-1869. Den 9. april 1869 emigrerer han til New York. ${ }^{6}$

Om tiden, til Elias 17 år gammel kom i tjeneste, beretter familietraditionen, at det ikke gik for godt med stedmoderen, så han blev anbragt hos en skrædder, vistnok da han kun var seks-syv år.

Elias lærte skrædderfaget, men næppe stort mere. Han kunne ikke skrive andet end sit eget navn (til måltagning ved arbejdet havde han sine egne tegn), og læsning kneb det stærkt med. Det var ret almindeligt at møde analfabeter i Sydsverige på den tid, ${ }^{7}$ så han skilte sig ikke ud.

Økonomisk var det trange tider for den svenske befolkning, og udvandringen var stor. I 1882 var ikke mindre end $37 \%$ af Københavns skræddersvende svenskere, ${ }^{8}$ men Elias standsede ikke som sine fagfæller i den danske hovedstad. Han foretrak Amerika, hvortil to søstre var emigreret i forvejen. Men han blev der ikke. Antagelig i 1878 rejste han hjemefter. På tilbagevejen fra Hamborg til Sverige fik han arbejde i Løjt, og året efter - den 21. februar 1879 - blev han gift med Kjestine Marie Rasmussen, der boede i Løjt Kirkeby. Det betød dog ingenlunde, at han slog sig til ro.

Den 27. juli 1883 rejste Elias Svensson påny til Amerika. Han ville gerne have haft familien med, men hans kone sagde nej. Hun vidste af breve fra udvandrede løjtinger i Amerika, at de længtes hjem. Så familien blev først 


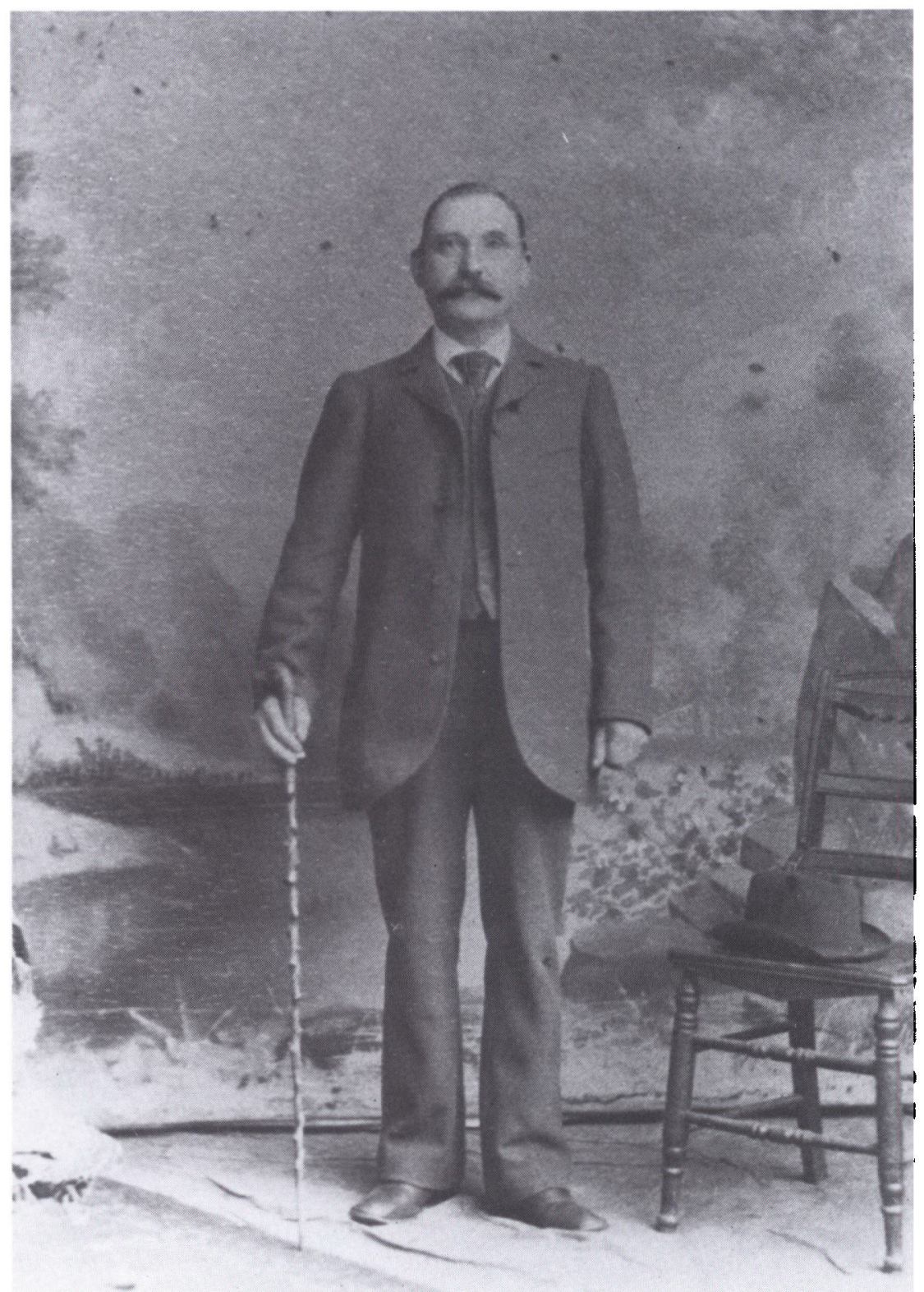

A. Svenssons far Elias Svensson (1847-1908). Historiske Samlinger. 
forenet igen, da Elias vendte tilbage den 23. august 1884. Men uroen sad ham stadig i blodet. Den 2. april 1889 tog Elias påny til Amerika, kom ganske vist tilbage året efter, men udvandrede igen 1891. Denne gang var han borte i fire år og genså først sit hjem den 12. juli 1895 .

Selv om Elias Svensson en tid havde så stor omsætning, at han havde svend, kan man ikke opbygge en sikker kundekreds på denne måde. Konfektionstøjet gjorde det ikke lettere at være skrædder, hvis man ikke tog det $\mathrm{i}$ forhandling. Han var heller ikke den eneste skrædder på stedet. Resultatet blev, at hans kone i almanakken for 1896 noterede, at 5. juni »rejste min mand til Sverige for at bosætte sig der«.

Når det ikke drejede sig om Amerika, men om Sverige var Kjestine villig til at følge efter. I almanakken noterede hun:

21. juli "solgte jeg mit hus, mit gamle barndomshjem for $1000 \mathrm{M}$., fordi vi, om Gud vil, skal rejse til Sverige.«

29. august »holdt jeg auktion paa mine møbler, det holdt daarligt ud. Det var en meget mørk dag for mig og Tilde.«

21. oktober "rejste Tilde og jeg fra vort gamle barndomshjem ... til Eldsberga, hvor vi ankom søndag den 25 . oktober om aftenen lykkelig og vel og traf min mand sund og rask."

Tilde (Bothilde Bondine) Svensson, født den 10. juni 1885, var netop fyldt 11 år, da de flyttede til Sverige. A.S., der nu var 15 år, fulgte ikke med, men kom på Hejls efterskole ${ }^{9}$ den 1. oktober 1896, og han så siden kun sin far på enkelte besøg i det svenske hjem.

Heller ikke i Sverige kunne Elias Svensson slå sig til ro. Han lånte penge til nye Amerikarejser. I 1904 rejste han til New York den 21. april, kun to måneder efter sit sølvbryllup, med hjemkomst den 27. marts 1905. Ny afrejse den 22. marts 1906 - denne gang til St. John i Canada - med hjemkomst den 4. april 1907. ${ }^{10}$ Men det var den sidste rejse. Juleaften 1907 blev han syg, og han døde en måned senere.

Kjestine Svensson blev boende i Sverige under disse Amerikarejser. Datteren Tilde ville gerne være lærerinde, men hendes danske hjemmesprog og den tyske skolegang slog for stærkt igennem til, at hun kunne blive optaget på det svenske seminarium. I stedet lærte hun kjolesyning, og efter faderens død flyttede Tilde med sin mor tilbage til Sønderjylland, hvor hun oprettede systue på Kegnæs. I systuen hang indrammet et amerikansk byprospekt med rygende fabriksskorstene, et minde om faderens urolige tilværelse. Det var vist fra Chicago. Men Tilde samlede sig om nærmere mål. Da hun efter moderens død i 1936 kunne følge sin egen lyst, blev hun hjemstavnsforfatter."

Det var ikke så meget, A.S. under sin opvækst havde set til sin far. Amerikaopholdene havde jo fjernet faderen fra A.S. sammenlagt seks år, først medens 
A. Svenssons mor Kjestine Marie Svensson fodt Rasmussen (1847-1936). Her gengivet efter Sonderjydske Kvinder under Fremmedherredommet II 1931 s. 85.

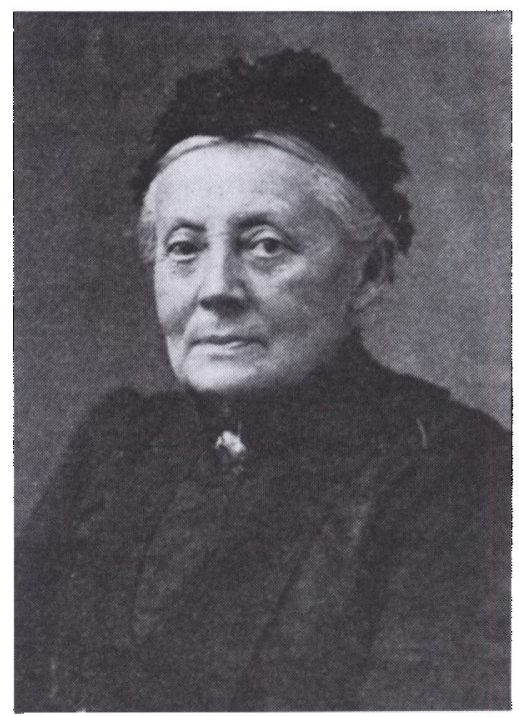

han var 2-3 år, senere på alderstrinnet 8-9 år og igen fra han var 10, til han var fyldt 14 år, altså ialt halvdelen af disse barneår. Intet under, at han havde svært ved at forstå sin far.

I familiefaderens fravær var det morfar Bunde Rasmussen, der var mand $\mathrm{i}$ huset. Han stammede fra Børsmose i Aal sogn ved Varde, var blevet uddannet som skibstømrer i Aabenraa og gik på langfart som skibstømmermand, indtil sønnen Bertel blev skyllet overbord fra Fanøbriggen Acmel ved San Fransisco den 27. september 1855. Bunde Rasmussen, der var med samme skib, tålte derefter ikke længere sejlskibene, men nøjedes med båd og fiskeri. Børnebørnene kendte ham kun som en fåmælt og indesluttet, noget tungsindig enkemand, der havde trukket sig tilbage til en lille lejlighed med stue og køkken i den ene ende af huset. Deres mormor, Botilla (Bodel eller Boel) Bertelsdatter, var død den 18. oktober $1880 \mathrm{i}$ en alder af 75 år, kun en måned før drengens fødsel. Manden overlevede hende i 13 år.

Botilla, hvis far havde måttet gå fra slægtsgården i Bodum ${ }^{12}$ under den store krise efter statsbankerotten, hørte til en slægt, der gennem generationer havde været bosat på Løjt land og var repræsenteret på mange af gårdene. Nationalt var den delt, men Botilla hørte til en dansk gren, og Bunde Rasmussen var med, da danske skibstømrere i marts 1848 med økse på nakken demonstrerede mod slesvig-holstenerne i Aabenraa. ${ }^{13}$

Det var dog ikke anderledes, end at datteren Kjestine fra maj 1863 til maj 1865 var $\mathrm{i}$ tjeneste hos den tysksindede gårdejer Th.P. Jürgensen, Fladsten, 
hvor hun oplevede krigen 1864 (med store indkvarteringer på gården) og senere omvæltningen fra dansk til tysk styre.

A.S. modtog en stærk dansk påvirkning fra sin mor og sin morfar. ${ }^{14}$ Bunde Rasmussen købte en dansk ABC og lærte dattersønnen at læse dansk, før han kom i skole. Derimod forstod drengen ikke eet ord af det tyske sprog, hvilket forsåvidt var upraktisk, da skolen jo var tysk.

Hjemmet lånte danske bøger til drengen. Især A.D. Jørgensens »Fyrretyve Fortællinger af Fædrelandets Historie« giorde indtryk, fordi den gav samling på alt, hvad han havde hørt og læst. Drengen fik også lov til at holde Nordslesvigsk Børneblad, hvor han endda fik optaget et lille digt om at sejle. Men morbroderens druknedød lå tungt over den hjemlige atmosfære, så han kunne ikke få opfyldt et ønske om at stå til søs. Derimod fik det betydning, at han gennem indsendelsen af danske stile til børnebladet opnåede kontakt med dets udgiver, tobaksfabrikant M. Andresen, Aabenraa. ${ }^{15}$

I nogle erindringsglimt, A.S. nedskrev i sin alderdom, findes følgende afsnit: "En anden gang, det har altsammen været i første halvdel af 1890 'erne, tog Andresen mig med om til H.P. Hanssen i Nygade, hvorfra "Hejmdal«, som han var redaktør af, og som var vor daglige avis hjemme, blev udsendt. Han tog venligt imod mig, gik med os over $i$ en tilbygning, hvor vi traf et medlem

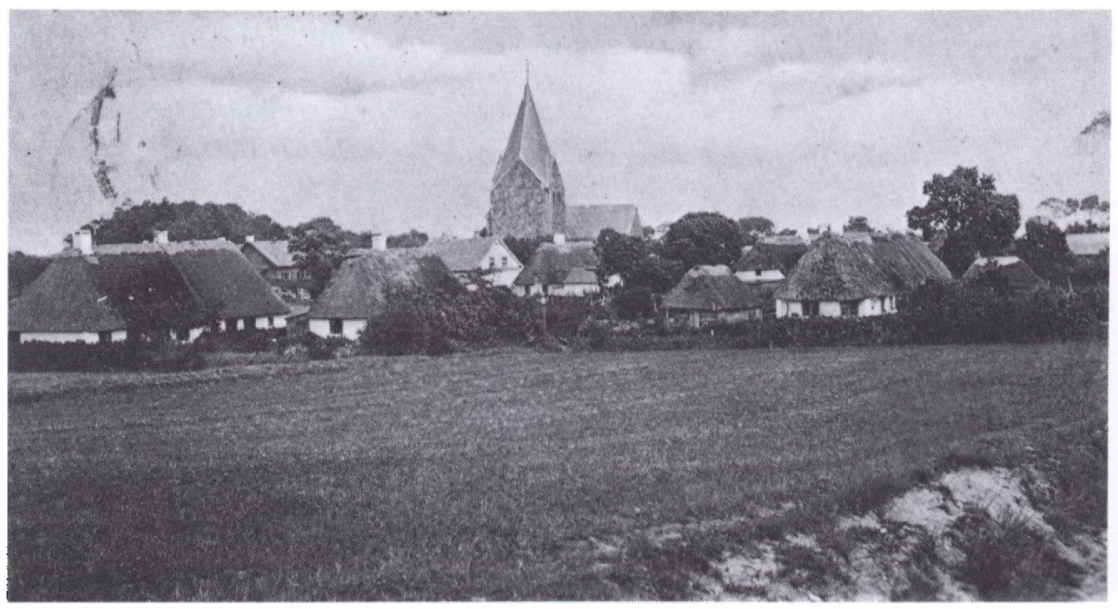

De strätakte huse, der samler sig om Lajt kirke, var rammen om hverdagen for familien Svensson, til den i 1896 drog til Sverige. Pd dette postkort fra drhundredskiftet ses til venstre et hus med to skorstene. Det var et dobbelthus, hvor familien Knak ejede den del, der lå narmest marken, familien Svensson den del, der vendte ud imod Gildegade og kirken. Kjestine Marie Svensson folte det tungt, da hun matte bryde op fra hjemstavnen og afhande barndomshjemmet, som hun havde arvet efter sin far, matte salge moblerne og med datteren folge efter agtemanden til Sverige, medens sonnen blev efterladt pd en efterskole i Danmark til en uvis fremtid. Privateje. 
af redaktionen, A. Lebeck, staaende ved en pult i en ret medtaget jakke - den pæne, som han gik i byen med, hang i nærheden -, og derefter ind i trykkeriet, hvor trykkemaskinen var i fuld gang, og hvor jeg saa det ene nummer af bladet komme ud efter det andet. Vi var ogsaa oppe paa Hanssens arbejdsværelse, hvor der i et hjørne paa en høj sokkel saas en buste af den norske digter Bjørnstjerne Bjørnson, hvis navn jeg kendte fra et illustreret ugeblad, og hvor jeg beundrende iagttog de mange reoler langs væggene, fyldt med bøger. Før vi sagde farvel, gik Hanssen hen og tog en bog ud, som han forærede mig. Det var Sigurd Müllers »Haandbog i den danske litteratur«, smukt indbundet. Da jeg hen paa aftenen forlod Aabenraa efter en begivenhedsrig dag - det var vinter og maaneskin, og den frosne sne knirkede for hvert skridt, jeg tog -, knugede jeg den dyrebare gave ind til mig. Det var den første rigtige bog, jeg selv var ejer af, og det var med stolthed, den blev vist frem, da jeg var hjemme igen."

Selv om Elias Svensson regelmæssigt sendte penge hjem, fik A.S. tidligt til opgave at bidrage sit. Flere somre kantede han således torv ude i moserne, og en enkelt sommer var han - endnu ukonfirmeret - i tjeneste hos kaptajn Jens Rasmussen i Dyrehave. Han fik lov at komme hjem hver tredie søndag. Men selv tjenestedrenge måtte i skole; såvidt A.S. senere huskede, drejede det sig om to halve dage om ugen. Men da var han jæunligt så søvnig, at han "faldt hen « $i$ timerne. Heldigvis var læreren overbærende over for disse overbebyrdede tjenestedrenge.

\section{Pengeløs på Hejls efterskole}

Det stærkeste indtryk af familiens små kår får man af nogle breve, ${ }^{16}$ A.S. sendte til hjemmet i Sverige fra efterskolen i Hejls. Den 21. november 1896 skriver han tak for det brev, han fik til sin 16-års fødselsdag og som gav oplysninger om, hvordan de havde indrettet sig:

"Det glæder mig rigtignok, at I har saa køn en lejlighed, baade uden og inden til, og at det nye bohave ogsaa er smukt. Der er jo vist meget at betale, det ene med det andet, saa det vil ikke være saa let for Eder i førstningen, men det giver sig jo nok. Naar Gud vil unde Fader godt arbejde, saa kan I faa det meget bedre der end i det fortyskede Slesvig. Naturligvis vil det være mest ubehagelig for dig kære Moder og saa Tilde, men det er da bedre som at sul.. i Løjt, og saa gaar alt saadant som hjemve bort med tiden. Svenskerne er jo vist lige saa venlige folk som de i Løjt, og egnen der vist ogsaa."

A.S. oplyser, at forstanderens kone, fru Birkedal, ${ }^{17}$ havde sagt, at han godt måtte blive på skolen, hvis han ikke kom hjem i julen, og så fortsætter brevet: 
"I ved jo nok, at jeg vilde gerne hjem til jer, men hvis det koster for meget, saa vil jeg ogsaa nok blive her. Jeg har det jo godt, og saa er der jo intet $i$ vejen for det. Jeg gaar nu i de søndagsbukser hver dag, de andre duer ikke mere. Det havde jo altid været mit haab, at hvis jeg kom over til jer i julen, saa vilde Far vist faa mig et par bukser, men naar jeg nu ikke kommer hjem, hvad saa. Jeg maa nødvendigvis have lidt mere klæder, enten jeg, som pastor Diemer ${ }^{18}$ sagde, kom paa en højskole eller ogsaa til en bonde et aars tid først. Det ved jeg ikke endnu. Han lovede mig da, han vilde ved et møde, som snart skulde finde sted etsteds ved grænsen, tale med nogle betydelige mænd om den sag, om hjælp for mig. Trøjen begynder ogsaa at slides.«

A.S. fortæller om løst og fast i sine breve, men de to gennemgående problemer er økonomien med dens konsekvenser for tøjet og fremtidsudsigterne.

Økonomien kom han ind på straks i det første brev, han skrev efter ankomsten til Hejls. Det var stilet til moderen, som jo var alene tilbage i Løjt for at afvikle hjemmet inden flytningen til Sverige. A.S. gjorde rede for rejseudgifterne, der rummede uforudsete poster: "Jeg kom med nogle rejsekammerater op at se ruinerne af Koldinghus og museet der. Jeg troede, det kostede ikke, men 22 øre maatte enhver betale. Det var meget smukt der, men ak, pengene."

Uforudset var også, at han skulle betale $4 \mathrm{kr}$. for de bøger, der skulle bruges ved undervisningen, Så han måtte stifte gæld. Drengen konkluderede: »Bare du kunde sende lidt penge, thi det er ondt at være pengeløs i det fremmede. Og meget værre er det at have gæld. Jeg ved, kære Moder, det vil ikke være let, men du har jo tit skaffet udveje, og Vorherre har jo altid hjulpet. Det vil han ogsaa nok denne gang.«

I det følgende brev takker A.S. meget for seks kroner: "Men ak, de slog ikke til. Se, først kostede bøgerne $4 \mathrm{kr}$. 5 øre. Saa en tavle 35 øre. Og nu maatte vi ogsaa have gymnastiksko, som kostede $2 \frac{1}{2} \mathrm{kr}$. Altsaa har jeg 16 øre pr. rest. lkke engang nok til det brev, jeg nu skriver, saa du ser nok, der bliver ingen at gemme. Men hvis det var dig muligt at sende mig en $5 \mathrm{kr}$. til, saa kunde jeg vistnok klare mig herefter, thi de første og med dem de værste dage er jo overstaaet. Jeg ved, kære Moder, hvor haardt det vil være for dig, men hvorledes skal jeg skrive til dig, naar jeg ingen penge har, og hvad vasken; den koster ogsaa. Jeg kan ikke gøre for det. Kære Moder, jeg skal ikke give en øre til unytte, det kan du stole paa. Jeg har nu betalt alt, hvad jeg skylder, og de 16 øre er min ejendom.«

I det næste brev takker A.S. for fem kroner: "Jeg skal nu nok se at gøre alt saa godt jeg kan. Klæderne gaar det nok med for det første; kun har jeg det smaat med bukser. Det kønne tøj maa jo heran hver søndag, men hvis Far kunde faa mig en dragt tøj til i sommer, saa gik det jo nok. Det er værre med støvlerne, for snart har jeg ikke mere fodtøj; men saa længe jeg er her, 
holder de nok; hvis jeg saa fik en haandpenge, naar jeg kom i tjeneste, saa fik jeg dem vel forsaalet. Men om jeg faar en plads ved jeg endnu ikke.«

I næste brev: »Paa lørdag er det Birkedals fødselsdag. Der er blevet samlet sammen af os, og de fleste gav en krone, jeg gav 50 øre; saa var der nogle bøndersønner, som lagde 50 til, og jeg blev ogsaa skreven for en krone.« A.S. supplerede i øvrigt med et lille fødselsdagsdigt til forstanderen. I dette brev, dateret 10. december 1896, vender A.S. også tilbage til spørgsmålet om juleferien eller eventuelt nytårsrejse: »Og hvis jeg nu kom hjem til nytaar, saa kostede det naturligvis de penge, som jeg skrev, og saa kunde det være vanskeligt nok for Fader at faa mig et par nye bukser, og saa desuden lidt haandpenge; jeg har kun godt $1 / 2$ krone, naar brevet er afsted sendt. Og saa lovede jeg ogsaa, da jeg skrev til Niels Frederiksen, at jeg i julen vilde skrive til Maria og Joh. Roth, ${ }^{19}$, som jeg havde lovet. Desuden skylder jeg $1 \mathrm{kr}$. 40 hos husflidslæreren, som maaske skulde betales til jul. Saa det var vist bedst, om jeg fik lidt penge, og saa biede med at komme hjem til i sommer engang.«

A.S. kom ikke hjem hverken til jul eller nytår, men blev som den eneste elev tilbage på efterskolen, hvor forstanderparret tog sig kærligt af ham. Til gengæld sendte forældrene ham $10 \mathrm{kr}$. I takkebrevet forklarer han: "Jeg skal nu gøre det bedste, jeg kan. Jeg kender en skrædder her i byen, som jeg har faaet lappet mine bukser ved to gange. Ham vil jeg tale med om et par nye bukser, ellers skal jeg have et par i Kolding, naar de bliver for dyre. Jeg maa ogsaa have mig et par tøfler eller saadant noget, da de andre er i stykker skaarne. Gymnastikskoene er der hul paa, men jeg har lapper af tøj i dem, saa det kan gaa lidt endnu.«

\section{På vej mod en dansk gerning i grænselandet}

I brev efter brev aflægger A.S. nøjagtig beretning om de materielle problemer og den finansielle misere, men vi kan også følge hans overvejelser vedrørende fremtiden: "Forleden dag havde jeg en samtale med præsten, som gik mig haardt paa livet. Han sagde først, at han havde ikke faaet brev endnu fra Andresen, ${ }^{20}$ men at han vel kom herned, og en plads skulde de vistnok faa mig. For resten havde du dengang talt om, at $P$. Andresen vilde have haft en missionær ud af mig, men at det var godt, jeg ikke var bleven det, thi han havde lagt nøje mærke til mig og ikke fundet, at jeg lod noget haabe i den retning, da jeg ingen samkvem havde med Gud. Jeg sagde ikke noget, men tænkte, at han kunde tro, hvad han vilde, fordi han kan da ikke se ind i mit indre. Maaske har jeg ikke været tit $i$ kirke til en tid, men uden overfrakke og i en kold kirke ... det holdt jeg ikke af. Videre: Han kunde ikke gøre noget 
godt for mig mere, men skulde heller ikke gøre ondt for mig. Planen var jo, at jeg næste vinter skulde paa højskole. Nu skulde der jo nok blive tale om det. Jeg havde ikke opfyldt hans forhaabninger tildels, og der kunde jo nok blive noget af mig, men ikke mere end almindeligt. Jeg maatte huske paa, at jeg havde ingen penge. Det var formodentlig gaaet mig saadan, at der var blevet talt for meget om mig, og saa tænkte jeg selv mere, end jeg maatte. Jeg havde som sagt ingen interesse vist for religion, og nu vilde han sige mig, at skulde jeg frem, maatte jeg stedse være saaledes overfor dem, som skulde hjælpe mig, at de kunde være glade ved mig. (Som ogsaa var ret. Dog forstaar jeg ikke, hvad der var i vejen). Jeg har stedse søgt at være ordentlig, flittig og paapassende, saa jeg kunde lære noget. Dog nu faar Vorherre raade. Kanske er mine evner for ringe, eller jeg har ikke stræbt nok. Dog, jeg kan vel gaa min gang som andre mennesker. Skulde jeg ingen plads faa, maa jeg jo hjem til Eder. Og kommer jeg ikke paa skole næste vinter, vil jeg ikke tænke mere herpaa. Saa har jeg været her $i$ vinter, hvilket har givet mig mange gode dage, og tillige lidt kundskab; da præsten ikke mener, at jeg har opnaaet meget, tør jeg kun skrive lidt. Nu lader jeg staa til. Jeg føler i mig selv, at jeg dog en gang vil komme til at opfylde den plads, Vorherre har bestemt mig for, den være stor eller lille. Og saa forlanger jeg ikke andet. ... Bare I har det godt derhjemme, saa skal jeg nok klare mig.«

I et senere brev oplyses, at Andresen endnu ikke har været der, men at pastor Diemer har skrevet til ham. A.S. tilføjer: »Der er en plads at faa her i byen, ja to, men jeg kan jo intet gøre, før de kommer. Fru Birkedal har sagt, at hvis jeg kom over til Skau i Bukshave eller et sted her i nærheden, saa kunde jeg jo have mit hjem her hos dem. Jeg takkede og sagde, at det vilde jeg gerne, jeg kunde ingen bedre sted faa at gaa hen og raadføre mig om alting."

Endelig den 23. marts 1897 blev fremtiden såvidt afgjort for A.S. Han havde tilsyneladende fået brev hjemmefra om mulighederne i Sverige og skriver i sit svarbrev den 23. marts:

"Jeg modtog Eders brev igaar morges og blev baade glad og bedrøvet derover. Nu maatte det jo afgøres, hvorledes det skulde gaa mig. Da jeg imidlertid havde faaet at vide ved Thomsen, at Andresen og Skau kom paa tirsdag, altsaa i dag, vilde jeg ikke tale med fru Birkedal om noget. Vi blev meget eksaminerede allesammen, og begge var meget godt tilfredse. Derpaa fik jeg en samtale med dem. Andresen spurgte mig, om jeg har faaet brev fra Eder og hvad I skrev. Jeg sagde, at de skulde skaffe mig en plads i sommer og paa højskolen næste vinter, ellers skulde jeg hjem til Eder for at lære noget. Ja, det var jo ret. Nu havde han plads til mig hos Skau, hvis jeg vilde være der. Det vilde jeg jo nok. Saa skulde Skau og Andresen nok hjælpe mig videre 
frem paa en højskole næste vinter; saa skulde det jo nok vise sig, hvad jeg saa havde lyst til. Andresen: Jeg har jo altid sagt, at vi kan ikke springe i det $i$ en fart, men der maa tid til at udvikle sig. Skau: Jeg har stor fornøjelse af at hjælpe saadanne frem, som selv ville. (Præsten var meget flink, han har vist været gal $i$ hovedet forleden dag). Saa sagde han, Skau, at jeg skulde nok faa det godt der, og med hensyn til klæder og alt saadant noget og vask skulde hans husholderske nok hjælpe mig. Hun havde jo ingen at pusle med uden ham. Han skulde nok være samvittighedsfuld med hensyn til lønnen og ordne alt paa det bedste for mig (saa syntes jeg ikke, jeg vilde forlange bestemt). Jeg skulde nok faa lov til at rejse hjem en tid, men det maatte helst bie til efteraaret; saa havde jeg jo tjent noget, og saa kunde jeg jo ogsaa bedre fortælle jer, hvorledes alt lod sig gøre med skolen og disse ting. ... Nu tror jeg, I kan være rolige for mig for det første; jeg kunde jo ikke gøre anderledes og er selv godt tilfreds."

I en tilføjelse står: "Derefter skulde Skau jo nok indlede mig i hans bekendtskaber, sagde han, for udviklings skyld og til glæde for mig selv. Og saa kunde han jo ogsaa bedst anbefale mig, naar han lærte mig at kende. Vorherre give nu sin velsignelse dertil."

I et løsrevet brevark fra tiden, medens A.S. endnu ventede på denne afgørelse, nævner han en mand (hvis navn ikke står på arket), der lovede sammen med Andresen at ordne det, så det blev økonomisk muligt for ham at komme på højskole. "Saa skulde det nok vise sig, hvad jeg havde anlæg til, og jeg kunde være ganske trøstig. H.P. Hanssen havde gaaet den selvsamme vej og saa læst lidt bagefter. ... Jeg vilde jo vist komme til at indtage en stilling dernede i Sønderjylland en gang, hvis Gud ellers var med mig, og han troede nok, at jeg kunde bringe det til noget paa dette omraade. Naar Andresen kom ned, skulde vi faa nærmere at vide."

Med afgørelsen den 23. marts 1897 begyndte vejen at tegne sig.

A.S. blev meget glad for sine ophold på Bukshave - han var der to somre - og for Peder Skau, ${ }^{21}$ der tog sig meget omsorgsfuldt af ham. Det var ikke blot et godt tjenestested, men det var samtidig et lærested i sønderjysk historie. P. Skau havde selv varet med $i$ meget, men tillige havde han erindringer helt tilbage fra tiden, "da Sønderjylland vågnede«. Han havde i sin ungdom været kusk for professor Flor, og han fortalte, hvorledes han havde set sin ældre bror, Laurids Skau, gå bag laden og memorere sin forste store tale, den, der blev holdt på det berømte Skamlingsbankemøde 1843 .

En tredie sommer tjente A.S. som røgter hos Jørgen From, Fjelstrup. Et lille træk kan belyse den udvikling, A.S. havde gennemgået efter Hejlstiden. A.S. foreslog at anskaffe jerntøjrepæle, men Jørgen From sagde nej. Han ville beholde de gamle af træ. Alligevel gik A.S. hen og bestilte jerntøjrepælene, 


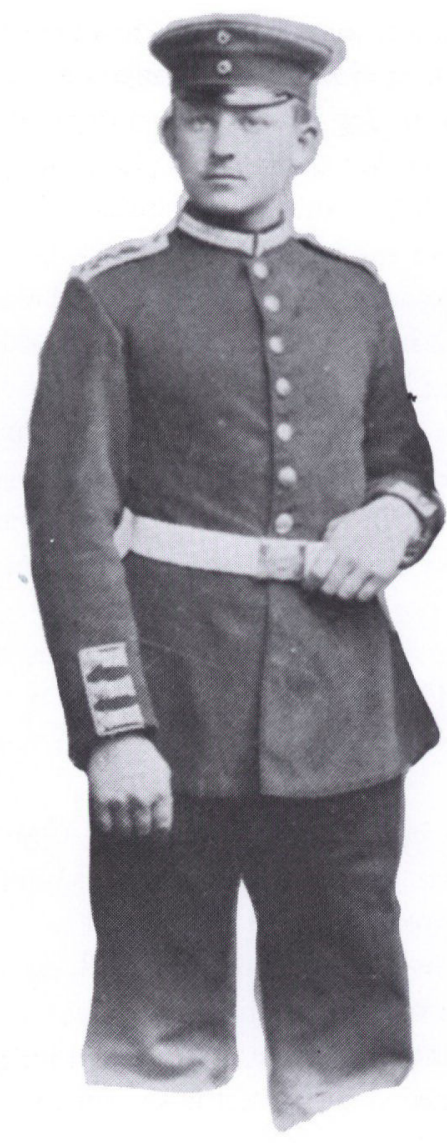

A. Svensson fotograferet i 1903 , da han gjorde tjeneste ved Kronprins Grenader-Regimentet $i$ Königsberg. Gengivet efter A. Svensson: Kamp og Fest I, 1960.

men erklærede, at han ville betale dem af sin egen lomme. Jørgen From brummede misbilligende, men affandt sig med sin selvrådige røgters disposition og betalte endda selv anskaffelsen.

Efter sommerens landbrugsarbejde var A.S. hver vinter på højskole, først på Vallekilde. Herom har han senere fortalt: ${ }^{22}$

"Paa Vallekilde opnaaede jeg frit ophold imod, at jeg var kakkelovnsmand. Jeg nyttede tiden godt. Jeg kan endnu huske, at jeg sad og læste historie, mens jeg ventede paa, at der skulde komme gang i kakkelovnene. Paa Testrup fik jeg ogsaa frit ophold; der var jeg lampemand. Jeg skulde pudse lamperne og passe dem med petroleum."

Efter Testrup kom A.S. til Askov: "Ved læsning af en pjece af pastor Rosenstand, Vester Vedsted, kom jeg i tanker om, at jeg maaske kunde blive frimenighedspræst. ${ }^{23} \mathrm{Jeg}$ deltog saa i et særligt kursus paa Askov, men kunde 
ikke rigtig med Appel, ${ }^{24}$ saa jeg afbrød, og en dag drog jeg af by, højt siddende paa et flyttelæs, og for resten uden at sige farvel til Appel først. Jeg kom saa til Nysted højskole, hvor jeg var en slags hjælpelærer for forstanderen, pastor Hans Hansen. Men derfra blev jeg indkaldt til militærtjeneste, og saa var det forbi med højskolen.«

Familiebesøgene i Sverige blev også til noget, men som P. Skau havde bebudet, måtte det første vente til efteråret. A.S. nåede dog frem til Trönninge ved Halmstad, hvor forældrene da boede, til moderens 50-års fødselsdag den 13. oktober 1897.

Det næste besøg har moderen registreret med ankomst den 24 . december 1898 og afrejse 6. januar. $\mathrm{Og}$ igen julebesøg $\mathrm{i}$ året 1900 med ankomst fra Askov den 22. december og afrejse til Nysted den 5. januar 1901. I oktober 1901 rejste A.S. til Königsberg for at aftjene sin prøjsiske værnepligt. Da han kom til skade, blev han fritaget for videre tjeneste den 17. april 1903.

\section{Dansk journalist}

Nu var det så, A.S. skulle finde sin livsvej. Rejsen til hjemmet i Sverige lagde han over Sønderjylland, hvor han besøgte gamle venner, medens han boede hos M. Andresen, Aabenraa.

M. Andresen havde stedse fulgt sin protegé fra stilskrivningen til søndagsbladet med varm interesse. Det fremgår af de breve fra Andresen til A.S., der ligger i Svenssons privatarkiv i Landsarkivet, at han altid var parat med hjælp og støtte, med vejledning og gode råd. $\mathrm{Og}$ med beroligelse for så vidt angik fremtidsudsigterne. Den 5. december 1899 skrev han således:

"H.P. Hanssen, Hejmdal, har en gang talt om, at han maaske kunde faa brug for dig. Nu kan du jo ved lejlighed skrive til ham, eller mon du ikke kommer herned paa egnen ved juletid. Forøvrigt haster det jo ikke med at tage bestemmelse angaaende denne sag. Vi har jo endnu tiden for os.«

I 1903 var tiden inde. Da lykkedes det M. Andresen at hjælpe A.S. ind i den fremtid, de så hyppigt havde drøftet. Det blev ikke Hejmdal, men Flensborg Avis. Ikke H.P. Hanssen, men Jens Jessen.

M. Andresen fik under et besøg i Flensborg at vide, at redaktør Jessen søgte en ung mand, fordi redaktør $P$. Simonsen var gået $i$ gang med at afsone en fængselsstraf på halvandet år, ${ }^{25}$ og Andresen spurgte nu A.S., om han ikke havde lyst til at blive journalist. Det havde han. Tanken havde tidligere sysselsat ham uden dog at tage fastere form. Men betingelsen var, sagde Andresen, at han tog fat i Flensborg straks.

Næste morgen rejste A.S. derfor ikke til Sverige, hvor hans forældre for 
resten havde et halvt løfte om en stilling som stationsskriver til ham, men til Flensborg, hvor han meldte sig hos redaktør Jessen. Det var den 6. maj 1903, at redaktør Jessen antog den unge mand - A.S. var nu 22 år - til journalistisk uddannelse og menneskelig videreudvikling. Og bedre læremester end Jens Jessen kunne A.S. ikke have ønsket sig.

Det var langtfra, at en løbebane som dansk journalist i Sønderjylland havde kunnet regnes til fremtidsudsigterne for en dreng, der var blevet født som svensk statsborger under tysk styre. Han ville når som helst kunne udvises af de tyske myndigheder, dersom de fandt ham til besvær. På de vilkår kunne man ikke arbejde som dansk journalist under Fremmedherredømmet.

Efter at Bismarck 1890 var blevet styrtet som tysk rigskansler, kom der imidlertid en pause med en lempeligere udenrigspolitik, der indbefattede en mere velvillig holdning over for ansøgninger om prøjsisk statsborgerskab i det sønderjyske grænseland. Elias Svensson benyttede lejligheden - formodentlig efter tilskyndelse fra ægtefællen - og indgav ansøgning, og hele familien opnåede sikkerheden $\mathrm{i}$ et prøjsisk statsborgerskab den 12 . juni $1891,{ }^{26}$ hvorefter familiefaderen påny udvandrede til Amerika! Uden bevilling af dette statsborgerskab, der vel næppe kunne tænkes givet på noget andet tidspunkt, ville A.S. ikke kunne være gået ind $i$ et dansk arbejde $i$ Sønderjylland.

Der havde tegnet sig andre forhindringer: Hvis moderen havde sagt ja til

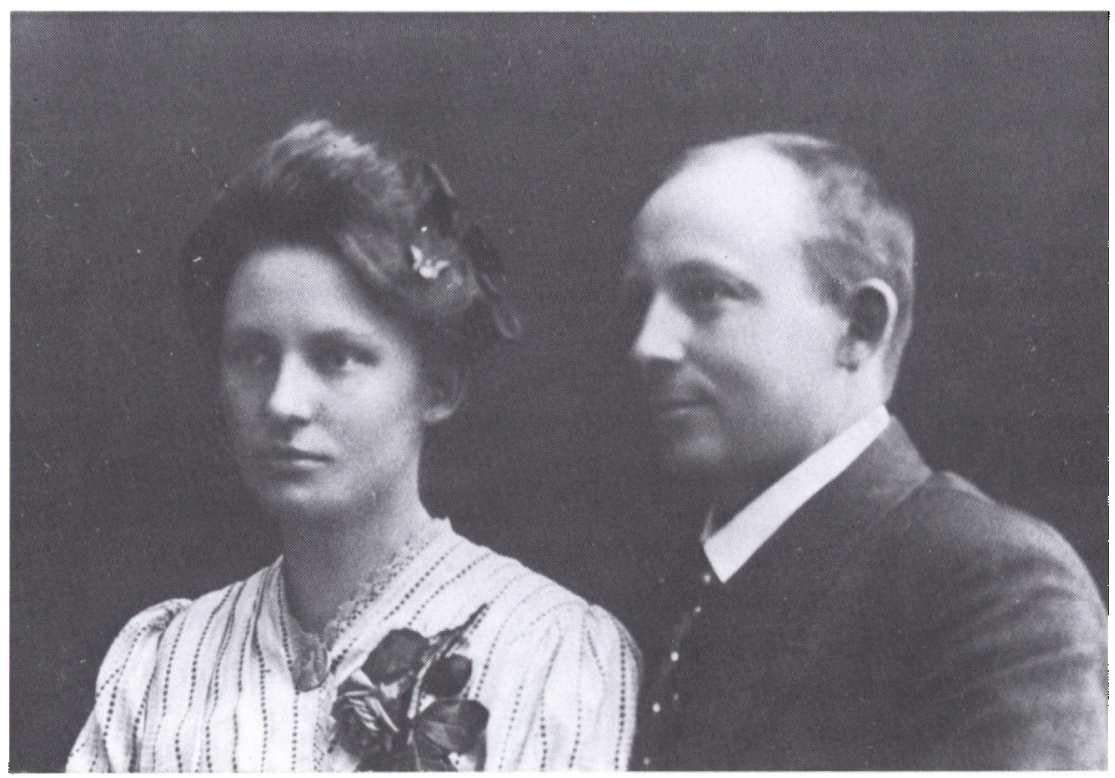

A. Svensson og hustru Kathrine Marie fodt Billum (1884-1976). Foto o. 1907. Historiske Samlinger. 
at følge manden i emigration til Amerika, var familien antagelig faldet til ro derovre og altså være gået tabt for Sønderjylland.

Havde A.S. fulgt familien til Sverige i 1896 i stedet for at tage på efterskole i Hejls, er det også et åbent spørgsmål, hvad han var blevet til.

I Hejls måtte A.S. så på egen hånd søge at få afklaret problemerne omkring sin fremtid, og først den 23. marts 1897 opnåede han den afgørelse, som ved at kombinere landbrugsarbejde i Sønderjylland om sommeren med ophold på danske højskoler om vinteren banede vejen for en dansk gerning i Grænselandet. Til det sidste havde der været mulighed for, at A.S. blev henvist til at søge sin uddannelse og fremtid i Sverige, skønt hans hu stod til Sønderjylland.

Det var noget af et tilfælde, at vejen blev den journalistiske. A.S. havde tumlet med andre planer. Så sent som i 1906 var de endnu ikke opgivet. Det fremgår af det brev, redaktor Jens Jessen som nævnt $\mathrm{i}$ indledningen skrev til fru Svensson ${ }^{27}$ den 28. maj 1906. Efter at redaktør Jessen havde udtrykt sin glæde over et brev, han havde modtaget fra A.S., fortsatte han: "Kun skal han ikke vælge at være i hovedsagen vandrelærer, agitator, vejleder osv., for det er en kedelig stilling i længden. Det er langt mere tilfredsstillende at være en veltjent journalist. Men alt dette klarer sig nok."

To måneder efter var Jens Jessen død. De deraf følgende rokeringer $\mathrm{i}$ den sønderjyske presse placerede A.S. som forpagter og redaktør af det danske blad i Sønderborg, Dybbøl-Posten. Det var imod H.P. Hanssens ønsker og bestræbelser; han ville have en af sine egne folk på posten og modsatte sig valget af en af Jessens elever. ${ }^{28}$ A.S. var kun 25 år, da han blev udpeget til redaktør, og da han tiltrådte stillingen den 1. januar 1907, havde han 26 år gammel nået mål og fået pålagt opgaver og ansvar, ${ }^{29}$ som han ikke havde drømt om, da han på Hejls efterskole 10 år forinden havde kæmpet med de problemer, der lagde uvished over hans fremtid.

A. Svenssons vej til redaktørstolen er ikke blot beretningen om en dreng fra et fattigt hjem, som det gik over forventning godt, men den giver samtidig et billede af det sikkerhedsnet, som vågne, forstående og hjælpsomme danske mænd nord og syd for Kongeågrænsen havde spændt ud, for at ingen evner, der kunne udnyttes i nationalitetskampen, skulle gå til spilde.

NOTER

1. Brevet er aftrykt i »Flensborg Avis 1869-1969«, red. Poul Kürstein, Flensborg 1969, p. 162-164.

2. A. Svenssons beundring for læremesteren fremgår både af en mindetale, udgivet Odense 1906, og af det værk, han skrev, »Redaktør J. Jessen, Flensborg Avis« I-III, ialt 1000 sider, hvis sidste bind udkom 1960, da forfatteren var 80 år. De tre år på Flensborg Avis prægede A.S. for hele livet, endskent den unge journalist efter Jessens mening ikke blot havde et vanskeligt sind, men også var utilgængelig for gode råd (jævnfør de to breve, der er aftrykt i Sønderjysk Månedsskrift 1964 p. 297-302 og 1965 p. 297-299). Bemærkningen om det vanskelige sind gav ikke en 
rammende karakteristik, men har vel sigtet til det ret kraftige temperament, der hos A.S. var forbundet med en betydelig trang til at hævde egne standpunkter.

3. „Sønderjydske Kvinder under Fremmedherredømmet«, bd. II, udg. af Hanne Jensen, Christiane Lund og Bothilde Skjold, Kbh. 1931, p. 85-89.

4. A. Svensson var journalist ved Flensborg Avis 1903-06, redaktør af Dybbøl-Posten 1907-15, deltog i Verdenskrigen 1914-18, redaktør af Danskeren (senere Haderslev Stiftstidende) fra 1919, politisk redaktør ved Jydske Tidende 1929-45 og konservativ folketingsmand 1932-45, se i øvrigt Biografisk leksikon, 3. udg. bd. 14.

5. Gildegade nr. 13, hvor familien ejede hælvten af et dobbelthus, medens Maria Knak (se note 19) og hendes mand ejede den anden halvdel. I 1983 er dobbelthuset, der stammer fra 1820'erne, blevet ombygget til et enfamiliehus.

6. Oplysningerne givet af historiestuderende Per Knutsson, Örebro.

7. Richard Willerslev: "Den glemte indvandring - Den svenske indvandring til Danmark 18501914«, Kbh. 1983, p. 52 f.

8. Willerslev p. 142 f. Ialt er der registreret 200.000 , som i perioden $1860-1910$ er udvandret fra Sverige til andre europxiske lande, heraf 81.000 til Danmark, 28.000 til Tyskland. Til Amerika gik rundt 1 million. (Willerslev p. 25). Ifølge den prøjsiske befolkningsstatistik boede der i 1885 i Slesvig-Holsten 4.648 , som havde fodested i Sverige.

9. Da den tyske skole i Sønderjylland bekæmpede det danske sprog og tilsidesatte kendskabet til danske forhold, blev der af hensyn til de sønderjyske børn indrettet en række efterskoler lige nord for Kongeågrænsen, de såkaldte grænseskoler i Skibelund, Hejls, Holsted, VesterVedsted, Bramminge og Skanderup. Da Hejls efterskole, der fra 1891 blev drevet af De samvirkende sønderjyske Foreninger, var blevet overflødiggjort ved Genforeningen, overgik bygningerne til kommunal skole.

10. Fra ca. 1900 satte Canada med held stærkt ind for at fả sin part af udvandrerne, jfr. Kristian Hvidt: "Flugten til Amerika", Aarhus 1971, p. 390 og "Nordisk Emigrationsatlasu, Uddevalla 1980, p. 17 og 28 samt atlasblad nr. 9. - Tilbagevandringen af emigranter er det svært at gøre op, men den har varet betydelig; for Sverige er den for perioden 1876-1924 anslået til 18 pct., jfr. Keijo Virtanen: "Settlement or return«, Helsinki 1979, p. 68. Gerhard Kortum har i "Die deutsche und skandinavische Amerikaauswanderung im 19. und 20. Jahrhundert«, udg. af $K$. D. Sievers, Neumünster 1981, opstillet tilbagevandringstyperne med en gruppe 5, der omfatter "Wanderungspendler«. Til denne lille gruppe hørte Elias Svensson.

11. Biograferet af J. Slettebo i "Sønderjyske historikere efter 1864", Aabenraa 1976, p. 157 f.

12. Jes M. Holdt: "Gaarde og slægter i Løjt sogn«, Aabenraa 1982, p. 191.

13. Skibstømrernes nationale engagement og betydning i Aabenraa fra 1845 er påvist af G. Japsen i »Den nationale udvikling i Aabenraa $1800-1850 \ll$, Aabenraa 1961, p. 191, 212-214, 227-230, 236-239, jfr. også H.H. Worsøes skildring i "Aabenraa bys historie«, bd. 2, Aabenraa 1967, p. $189 \mathrm{f}$. specielt med henblik på martsdagene 1848 .

14. A.S. har fortalt, at man hos faderen, der havde lart sig dansk, aldrig mærkede til en nationalt afvigende holdning.

15. Mathias Andresen (1858-1916), der påbegyndte udgivelsen af "Illustreret Børneblad for Nordslesvigu i 1890 , fik en central stilling i det folkelige arbejde i Sønderjylland. Han sagde sin stilling som lærer op i 1887 , fordi han ikke ville være med til at fortyske danske børn, blev derefter en tid (indtil 1892) journalist, valgtes i 1889 til formand for Sprogforeningens bogudvalg, udførte et stort arbejde for Sprogforeningens almanak og Den blå sangbog. Formand for Sprogforeningen fra 1900 til sin død i 1916. Købte en tobaksfabrik i 1897. - Som for A.S. var det også for Ernst Christiansen (chefredaktør for Flensborg Avis fra 1906 til 1940) stilskrivningen til Nordslesvigsk Børneblad, der banede vejen til journalistik, se artiklen "Ung mands tanker om fremtiden« $i$ »Barn i Flensborg 1890-1920«, red. Poul Kürstein, Flensborg 1972.

16. Findes i Landsarkivet, Aabenraa.

17. Lorens og Kristiane Birkedal var et meget respekteret og afholdt forstanderpar, der havde et fint samarbejde med sognepresten, Vilh. Topsøe, men blev tvunget bort af dennes efterfølger, pastor P. Diemer, som virkede i Hejls 1886-1902. Brev herom fra Birkedal til A.S. 5. marts 1899 
(i Svenssons privatarkiv, Landsarkivet i Aabenraa), sml. kritiken af forstanderens begrænsede myndighed i Jørgen Ravns artike] »Mit liv og mit virke« i Sønderjyske Aarbøger 1971, p. 227.

18. Peter N.T. Diemer, der var født i Tønder 1850 som søn af farver og rådmand, senere stænderdeputeret A.T. Diemer, skildres i »Dansk Præste og Sognehistorie«, bind X, p. 252 som »den stive embedsmandstype, fjern og utilnarmelig«. Efter hans brud med Birkedal løste en mindre kreds sognebånd til pastor Højmark i Gaarslev.

19. Brøndgraver Johannes Roth og Maria Knak hørte til de narmeste naboer i Løjt. Blandt de andre, A.S. i Hejlstiden vedligeholdt brevforbindelse med, var også pastor Karl Heinrich Andresen, der var andenpræst i Løjt 1895-1907, senere sognepræst i Agerskov. Da Indre Mission blev spaltet i 1912, hørte Andresen til den gruppe tysksindede, strengt missionske præster, der udtrådte af I.M. og grundlagde Det gamle budskabs Indre Mission i protest imod Hans Tonnesens ledelse af I.M., som forekom dem at være for imødekommende over for de danske sønderjyder.

20. Den Andresen, der skulle bringe A.S. videre fra Hejls, må være $M$. Andresen (se note 15). I brev af 20. jan. 1897 taler A.S. ganske vist både om en P. Andresen og en mjournalist Andresen« (»Pastor Diemer har hilset mig fra journalist Andresen; han kommer en af dagene, saa skal jeg i forher. Saa skal jeg nok skrive hjem igen, hvad udfaldet bliver.«). Muligvis kunne der da vare tale om højskolemanden Peter Andresen, som 1893-95 var journalist ved Hejmdal. Men den P. Andresen, der omtales i samme brev, er dog sikkert pastor A. (se note 19), hvor P. som i andre tilfælde står for pastor. $\mathrm{Og} \mathrm{M}$. Andresen havde jo også været journalist.

21. Peder Skau (1825-1917), som på det tidspunkt var 70 år, var en fin personlighed, der havde en fremtrædende plads i de sønderjyske rækker. Han var således talsmand for den sønderjyske deputation, som den 7. december 1864 tog afsked med kong Christian IX i Kolding, han var med i den deputation, som i 1866 tog til Bismarck og den prøjsiske konge i Berlin i forsøg på at få tilsagnet $i$ Pragfredens $\$ 5$ om en afstemning realiseret, og han var igen ordfører for den deputation, som i januar 1899 over for overpræsident v. Köller protesterede imod den skærpede udvisningspolitik. P. Skau havde varet en god støtte for Hejls efterskole, jfr. "Sønderjysk Skoleforening 1892-1942 , Kolding 1942, p. 21 f. og Simon Hansen: wHejls efterskole fra 5. oktober 1891 til 10. september $1920 \ll$, Helsingør 1920, p. 5 og 11. Peder Skau, der i øvrigt fra begyndelsen i 1889 var medudgiver af Sønderjyske Aarbøger, har skrevet sine erindringer i "Minder fra mit liv og min tid", Aarhus 1909.

22. Interview i Dannevirke 2. maj 1953.

23. Otto Rosenstands pjece "Aandelige forhold i Sønderjylland " havde givet genlyd på Testrup højskole. Det gjaldt især to af eleverne på vinterholdet 1899-1900, A.S. og Hans Jefsen Christensen (senere formand for Skoleforeningen). Hos den sidste banede den vej for forståelsen af »den langt dyberegående fare end politiregimentet for danskhedens fremtid $\mathrm{i}$ Sønderjylland, der lå $\mathrm{i}$ bagholdsangrebet på det danske sprog og dansk ånd gennem fortyskningen af skolen og kirken« (»Sønderjysk skoleforening 1892-1942«, p. 105). Og Rosenstands fremhævelse af den betydning, danske frimenigheder i Sønderjylland kunne få nationalt, havde altså appelleret så stærkt til A.S., at det forte til tanken om at blive frimenighedsprast.

24. Jacob Appel (senere undervisnings- og kirkeminister), som i 1891 var blevet gift med Ingeborg Schrøder, datter af Askovs forstander, var medbestyrer af højskolen og forestod det kursus, A.S. forlod i 1900. A.S. var fra flere sider blevet advaret imod at forlade Askov. M. Andresen formanede ham således indtrængende i et brev af 24. november 1900 til at wlade Askov beholde ledelsen af hans uddannelse«. Den 27. december fortsatte $M$. Andresen med at indskarpe: De unge maa give efter og bøje sig for de ældre, særlig elever overfor lærere, og dette selv om man føler, at man forurettes derved.« Også H.P. Hanssen blev impliceret i sagen med henblik på at kontakte Appel. Men alt prellede af på A.S.

25. Straffen, der blev afsonet fra 9. marts 1903 til 9 . september 1904, var idømt for to forhold, dels en notits, der satte spørgsmålstegn ved berettigelsen af, at Overlandsretten havde godkendt udvisningen af en optant og en optantsøn, dels en skarp indsigelse imod et blad i Kiel, der havde prist den tyske fest på Knivsbjerg på bekostning af en sommerfest på Skamling (se A. Svensson: "Redaktør J. Jessen«, bd. III, Aabenraa 1960, p. 192-196). Det var denne hårde dom, der åbnede plads for ansættelsen af A.S. 
26. A.S. har fortalt, at han med skolen har måttet tage til tysk Knivsbjergfest, fordi familien måtte være forsigtig af hensyn til det svenske statsborgerskab, men det angivne motiv må bero på en erindringsforskydning. Den første Knivsbjergfest blev holdt $i \mathrm{1894}$, altså tre år efter, at det svenske statsborgerskab var blevet erstattet af et prøjsisk. Deltagelsen i skoleturen til Knivsbjerg har måske skyldtes en hensyntagen til ønsker hos husbonden, A.S. tjente hos.

27. Den 11. maj 1905 blev A.S. gift med Kati (Kathrine Marie) Billum, f. i Haderslev 30. januar 1884 som datter af købmand, senere varftsbogholder Morten Billum og Dorthea, f. Terkelsen. Kati Sv. har fortalt om sin opvækst i Flensborg i bogen "Barn i Flensborg 1890-1920«, Flensborg 1972, p. 37-55. Et tilbageblik over sit liv har hun givet i et interview i Dannevirke den 26. januar 1954.

28. A.S. blev valgt til redaktør af Dybbøl-Posten med otte stemmer mod én. Denne ene var Vælgerforeningens formand, P. Reimers, der havde lovet H.P. Hanssen at stemme på Nikolaj Andersen (A. Svensson: "Kamp og fest $\ll$, bind I, Sønderborg 1960, p. 14). Til trods for dette udgangspunkt og senere lignende kontroverser, der ikke svarede til H.P. Hanssens almindelige storsind, var A.S. under Fremmedherredømmet aldrig karrig med sin støtte til H.P.H. som sønderjydernes forer, bortset naturligvis fra de situationer, hvor han sagligt måtte reservere sig sin stilling. Det bliver gerne overset, når forholdet H.P.H.-A.S. nævnes blandt de klassiske modstanderkombinationer i nyere sønderjysk historie, jfr. Bjørn Svenssons artikel »En fejde, der satte dybe spor «, Jydske Tidende 16 . november 1980.

29. Herom afsnittet $" A$. Svenssons bedrift « $\mathrm{i}$ Peter Kr. Iversens fremstilling $\mathrm{i}$ "Sønderborg bys historie«, bd. II, Aabenraa 1966, p. 42 ff., jfr. også A. Svenssons erindringsbøger "Kamp og fest«, I-II, Sønderborg 1960 og 1961. 